\title{
Different types of tumors in perimenopausal women presenting with ovarian masses at a Tertiary Care Hospital.
}

1. MBBS, FCPS

Senior Registrar Gynae \& Obs Lady Atchison Hospital KEMU.

2. MBBS, FCPS

Assistant Professor Gynae \& Obs Lady Atchison Hospital KEMU.

3. MBBS, FCPS

Assistant Professor Gynae \& Obs Lady Wellington Hospital KEMU.

4. MBBS, FCPS

Assistant Professor Gynae \& Obs Lady Wellington Hospital KEMU.

5. MBBS, FCPS

Assistant Professor Gynae \& Obs Lady Wellington Hospital KEMU.

Correspondence Address:

Dr. Mahham Janjua

Department of Gynae \& Obs

Lady Atchison Hospital KEMU.

mushtaqm1985@gmail.com

Article received on:

$18 / 05 / 2020$

Accepted for publication:

20/08/2020

\begin{abstract}
Maria Akmal', Mahham Janjua², Rabia Wajid ${ }^{3}$, Maria Imran ${ }^{4}$, Zobia Jawad $^{5}$
\end{abstract}
ABSTRACT... Objectives: To determine frequency of benign and malignant tumors among perimenopausal women presenting with ovarian masses at a tertiary care Hospital. Study Design: Descriptive Cross Sectional study. Setting: Department of Obstetrics \& Gynecology, Jinnah Hospital, Lahore. Period: Six Months from August 2017 to January 2018. Material \& Methods: A total 127 premenopausal females with ovarian masses visiting Obstetrics \& Gynaecology Department, Jinnah Hospital, Lahore were selected. After detailed medical history and clinical examination patients underwent ultrasonography to diagnose status of ovarian masses. Data was entered in self-made proforma. Results: Total 127 patients were selected. Mean age of cases was $48.87 \pm 3.04$ years, with mean BMI of $26.52 \pm 2.43 \mathrm{~kg} / \mathrm{m}^{2}$ and obese patients were $30.7 \%$. Out of all $73.2 \%$ patients had benign masses and $26.8 \%$ patients had malignant masses. Obesity and family history were significantly correlated with malignant tumors among premenopausal women having ovarian masses $p$-value 0.001 . Conclusion: It was observed that the malignant tumors are frequently linked to pre-menopausal women with ovarian masses. Obese and family history positive patients are on high risk of malignant tumors.

Key words: Malignancy, Ovarian Masses, Ultrasonography.

Article Citation: Akmal M, Janjua M, Wajid R, Imran M, Jawad Z. Different types of tumors in perimenopausal women presenting with ovarian masses at A Tertiary Care Hospital. Professional Med J 2020; 27(11):2469-2473. https://doi.org/10.29309/TPMJ/2020.27.11.4874

\section{INTRODUCTION}

Around $10 \%$ of females undergo certain form of surgical procedures in lifetime for ovarian mass and discrimination of such ovarian lesion has significant value in our gynecological practices. ${ }^{1}$ Most ovarian cysts and masses are benign in premenopausal females. ${ }^{2}$ The average occurrence of ovarian cyst showing symptoms among malignant premenopausal female is about 1 in 1000 cases, rising to 3 in 1000 cases at 50 years of age. ${ }^{3}$ In premenopausal female, preoperative discrimination between the malignant and the benign ovarian mass may be troublesome with no examination or procedure being explicitly higher regarding accuracy exceptional cases is tumors with germ cells including unique cancer marker elevations including human chorionic gonadotrophin (hCG) and alphafetoprotein (aFP). Two significant issues require answers: prejudice against malignant and benign adnexal masses as well as, if possible, selecting the correct surgical intervention. It has become well defined that the benchmark for diagnosis of ovarian cyst is ultrasonography. ${ }^{1,4}$ Classifying ovarian masses allows malignant subjects to be treated accordingly by gynecological oncologists who have been seen to standardize care and enhance survivability for therapy. ${ }^{5}$ In addition, proper classification of benign masses encourages the selection of ovarian disease cases who may not need treatment or are appropriate for minimal surgical procedure in case of intervention needed. Nonetheless, determining if a mass is malignant or benign is not an only clinically data, we have to learn when assessing which medication is necessary. It is becoming particularly important to understand the basic histology of the mass as treatment strategies are more personalized to a particular patient. ${ }^{5}$ Forecasting a mucinous marginal growth, for example, offers a potential for fertility-sparing treatment and will demonstrate the necessity of more gastrointestinal examination. 
With benign cancer, it is necessary to determine the existence of an endometrioma as well as the likelihood of actively infiltrating endometriosis while determining who must operate and the degree of surgery. The retrospective assessment of the vascular and morphological properties of a mass via ultrasonography by an investigator is highly useful in determining if a mass is malignant or benign. ${ }^{5}$ Several masses as well have characteristics that make it possible to make a reliable medical assessment of a specific pathology of a particular mass 5. Ultrasonography may provide diagnostics for the assessment of ovarian masses as a major imaging paradigm. With even strong confidence, Doppler Ultrasonography can cause ovarian masses to remain diagnosed as malignant or benign. Different methods have been practiced to classify ovarian masses, such as simple scoring schemes, pattern recognition strategy, logistic regression-based probability predictors, statistics based scoring systems, and complex mathematical prototypes like neural networks. These all reveal that the pattern recognition strategy encompasses easy understanding with greater accuracy contrasted to other techniques for forecasting malignancy. ${ }^{6}$ Saluja et $\mathrm{al}^{7}$ from India reported benign masses on clinical assessment to be 75 and malignancy in $25 \%$ while on ultrasound $70 \%$ benign and 30 $\%^{7}$ were malignant.

This proposed study has been planned to be conducted in perimenopausal women to determine pattern of ovarian masses in as there is no such study done in our population. Most of the studies conducted on this topic have been done in postmenopausal women and there is scarcity of data in this group, so the findings of my study will generate baseline database of our population which is helpful to design future advanced studies on this topic.

\section{MATERIAL \& METHODS}

This study was conducted Department of Obstetrics \& Gynecology, Jinnah Hospital, Lahore. It was a Descriptive cross - sectional study from Six months from August to January (2017-2018).
Sample size is 127 at confidence interval of 95 $\%$, using $p=30 \%$ (frequency of malignancy in ovarian masses) ${ }^{7}$ and margin of error $=8 \%$

\section{Inclusion Criteria}

a. Perimenopausal women with ovarian masses (irrespective of disease duration), as defined in operational definitions.

b. Age range $45-55$ years.

\section{Exclusion Criteria:}

a. Patients with recurrent ovarian masses.

b. Patients unwilling to contribute to current study.

A written consensus was received from every patient and they were briefed about objective and the procedure of the study, making them sure of provided information confidentiality and that the subjects who partake it current study will undergo no any risk. Detailed medical history, clinical examination and rutien laboratory investigations were carried out. Patients underwent ultrasonography to diagnose status of ovarian masses (benign/malignant). Benign tumors were defined as unilateral, without ascites, unilocular, smooth and cystic masses on ultrasound. ${ }^{8}$ Malignat tumors were defined as bilateral, with ascites, solid nodular and irregular, and multiocular on ultrasound. ${ }^{8}$ The data entry as analysis was carried out by the researcher through premeditated proforma and SPSS 20.0, respectively. The quantitative variables including $\mathrm{BMI}$ and age were offered as mean \& standard deviation. Frequencies and percentages were calculated for age groups, pattern of ovarian masses (benign/malignant), family history, residential status, socioeconomic status and obesity. Effect modifiers including parity, age, family history and obesity were controlled thru post-stratification and stratification chi-square test to know their effects on outcomes. P-value $\leq$ 0.05 was deemed significant.

\section{RESULTS}

This study comprised of a total of 127 patients with $48.87 \pm 3.04$ years of mean age of (least 45 years and extreme 54 years). Majority of cases i.e. 83 (65.4\%) were aged below 50 years. Mean 
parity was $3.15 \pm 1.25$ while 69 (54.3\%) had parity up to 3. Mean BMI was found to be $26.52 \pm 2.43$ $\mathrm{kg} / \mathrm{m}^{2}$ and obese patients were 39 (30.7\%), while family history was positive in 10 (7.9\%) patients. (Table-I)

According to ultrasonography findings, benign masses were seen in most of the patients as 93 $(73.2 \%)$ while malignant masses were noted in 34 (26.8\%) patients. (Table-II)

There was no significant association of age and parity with malignant tumors, while obesity and family history were significantly correlated with malignant tumors among premenopausal women having ovarian masses p-value 0.001 . (Table-III)

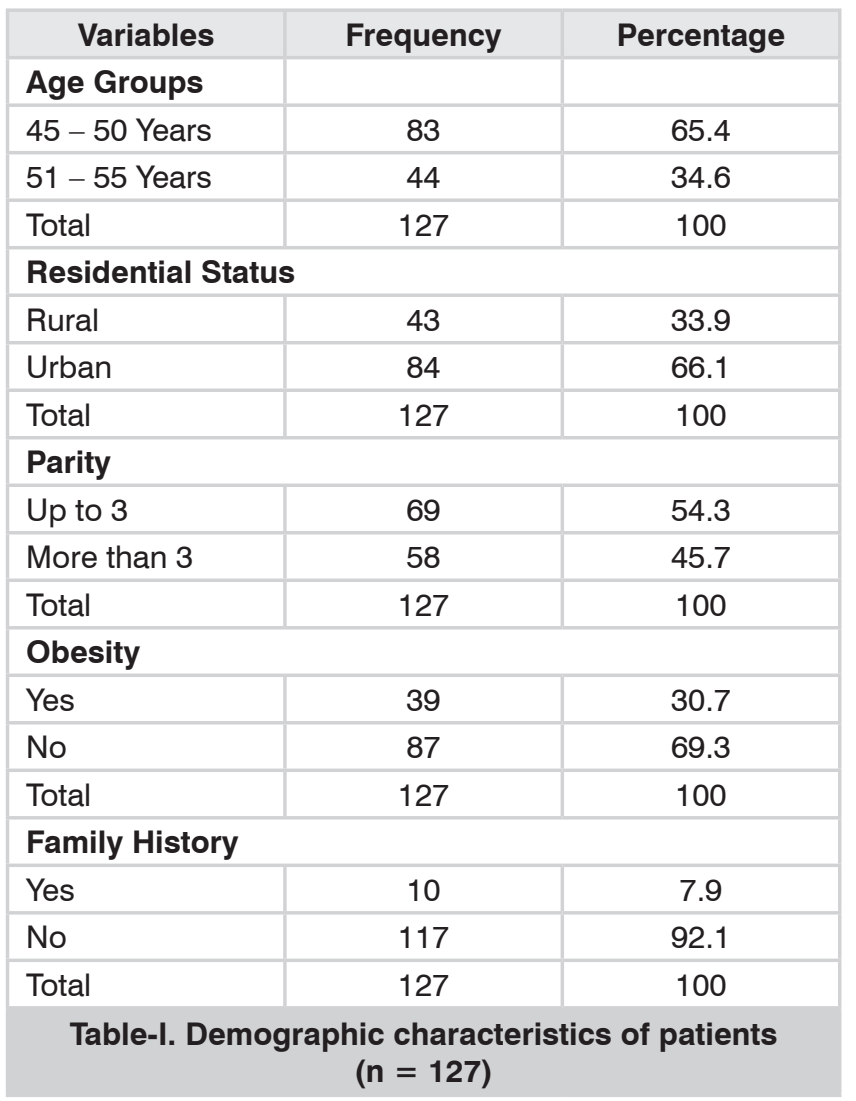

\begin{tabular}{|l|c|c|}
\hline Ovarian Masses & Frequency & Percentage \\
\hline Benign & 93 & 73.2 \\
\hline Malignant & 34 & 26.8 \\
\hline Total & 127 & 100 \\
\hline
\end{tabular}

Table-II. Pattern of ovarian masses among study cases $(n=127)$

\begin{tabular}{|c|c|c|c|c|}
\hline \multirow{2}{*}{\multicolumn{2}{|c|}{ Variables }} & \multicolumn{2}{|c|}{ Ovarian Masses } & \multirow{2}{*}{$\begin{array}{c}\text { P- } \\
\text { Value }\end{array}$} \\
\hline & & \multirow{2}{*}{$\begin{array}{c}\text { Benign } \\
64\end{array}$} & \multirow{2}{*}{$\begin{array}{c}\text { Malignant } \\
19\end{array}$} & \\
\hline \multirow{3}{*}{$\begin{array}{l}\text { Age } \\
\text { Groups }\end{array}$} & $\begin{array}{l}\text { Up to } 50 \\
\text { Years }\end{array}$ & & & \multirow{3}{*}{0.208} \\
\hline & $\begin{array}{l}\text { More than } \\
50 \text { Years }\end{array}$ & 29 & 15 & \\
\hline & Total & 93 & 34 & \\
\hline \multirow{3}{*}{ Parity } & Up to 3 & 50 & 19 & \multirow{3}{*}{0.844} \\
\hline & $\begin{array}{l}\text { More than } \\
3\end{array}$ & 43 & 15 & \\
\hline & Total & 93 & 34 & \\
\hline \multirow{3}{*}{ Obesity } & Yes & 15 & 24 & \multirow{3}{*}{0.001} \\
\hline & No & 78 & 10 & \\
\hline & Total & 93 & 34 & \\
\hline \multirow{3}{*}{$\begin{array}{l}\text { Family } \\
\text { History }\end{array}$} & Yes & 00 & 10 & \multirow{3}{*}{0.001} \\
\hline & No & 93 & 24 & \\
\hline & Total & 93 & 34 & \\
\hline $\begin{array}{r}\text { Table-III } \\
\text { to age }\end{array}$ & tificatio & ovaria & asses wit & $\begin{array}{l}\text { egards } \\
\text { 127) }\end{array}$ \\
\hline
\end{tabular}

\section{DISCUSSION}

Ovarian masses are quite prevalent and 10 percent of females have an ovarian mass-associated surgical procedure for its investigation throughout their lifetime. In current study patients revealed a mean age of $48.87 \pm 3.04$ years, where most cases $83(65.4 \%)$ were below 50 years of age. Farooq et $\mathrm{al}^{9}$ documented a mean age of 48.63 \pm 3.61 years that support the findings of current study. Similarly Ehsan et al ${ }^{10}$ supported current study by revealing a mean age of $47.3 \pm 3.8$ year.

In this study out of all 127 cases, $43(33.9 \%)$ were from rural regions and $84(66.1 \%)$ were urban residents, additionally 44 (34.6\%) were from poor socioeconomic status and 83 (65.4\%) belonged to middle income families. Saluja et al from India ${ }^{7}$ reported similar findings which are consistent to our study results.

In this study mean parity was $3.15 \pm 1.25$ while $69(54.3 \%)$ had parity up to 3 . Mean BMI in current study was $26.52 \pm 2.43 \mathrm{~kg} / \mathrm{m}^{2}$ with obesity presenting among $39(30.7 \%)$ cases, whereas family history was found positive among $10(7.9 \%)$ cases. Similar results were reported by Sharadha et al ${ }^{11}$ from India. 
In this study of these 127 study cases, ultrasonography findings revealed benign masses in $93(73.2 \%)$ while malignant masses were noted in $34(26.8 \%)$. Ashraf et al ${ }^{12}$ reported $65 \%$ benign masses while $35 \%$ malignant masses which supported current study outcomes. Saluja et al from India ${ }^{7}$ reported benign masses on clinical assessment to be 75 and malignancy in $25 \%$ while on ultrasound $70 \%$ benign and $30 \%{ }^{7}$ were malignant. These findings of Saluja et al ${ }^{7}$ also favored our findings. Parmer et $\mathrm{al}^{13}$ also reported $25.33 \%$ malignancy which as well backed current study findings. A study conducted by Ehsan et al ${ }^{10}$ reported $5.9 \%$ malignancy which is quite less than that being reported in our study.

\section{CONCLUSION}

It was concluded that the malignant tumors are frequently linked to perimenopausal women with ovarian masses. Obese and family history positive patients are on high risk of malignant tumors. Ultrasonography found to be quite efficient and reliable in diagnosis of ovarian masses. Early diagnosis and management can decrease the burden of this malignancy.

Copyright@ 20 Aug, 2020.

\section{REFERENCES}

1. Marret $H^{1}$, Cayrol $M$. Sonographic diagnosis of presumed benign ovarian tumors. J Gynecol Obstet Biol Reprod (Paris). 2013; 42(8):730-43.

2. Valentin $L^{1}$, Ameye L, Savelli L, Fruscio R, Leone FP, Czekierdowski A, et al. Adnexal masses difficult to classify as benign or malignant using subjective assessment of gray-scale and Doppler ultrasound findings: Logistic regression models do not help. Ultrasound Obstet Gynecol. 2011; 38(4):456-65.

3. Haan J, Verheecke M, Amant F. Management of ovarian cysts and cancer in pregnancy. Facts Views Vis Obgyn. 2015; 7(1):25-31.
4. Minig L, Otaño L, Cruz P, Patrono MG, Botazzi C, Zapardiel I. Laparoscopic surgery for treating adnexal masses during the first trimester of pregnancy. J Minim Access Surg. 2016; 12(1):22-5.

5. Sayasneh A, Ekechi C, Ferrara L, Kaijser J, Stalder C, Sur S, Timmerman D, Bourne T. The characteristic ultrasound features of specific types of ovarian pathology. International journal of oncology. 2015 Feb 1; 46(2):445-58.

6. Jung SI. Ultrasonography of ovarian masses using a pattern recognition approach. Ultrasonography. 2015; 34(3):173-82.

7. Saluja JK, Roy PK, Mahadik K. Validity of clinical signs and symptoms of ovarian masses. National $\mathrm{J}$ Integrated Res Med. 2014; 5(4):67-71.

8. Yeoh $\mathrm{M}^{1}$. Investigation and management of an ovarian mass. Aust Fam Physician. 2015 Jan-Feb; 44(1-2):4852.

9. Farooq F, Noman D, Humayun N, Naveed N, Haider A. Demographic differentials and histopathological patterns of ovarian masses. Biomedica. 2015; $31(2): 118-23$

10. Ullah E, Taj N, Usman K, Alam S, Manzur S. Accuracy of sonographic features to diagnose malignancy in ovarian cysts in a tertiary care hospital Bahawalpur - Pakistan. Biomedica. 2013; 29(2):73-7.

11. Sharadha $S^{1}$, Sridevi $T A^{2}$, Renukadevi $\mathrm{TK}^{2}$, Gowri $\mathrm{R}^{2}$, Binayak $\mathrm{D}^{2}$, Indra $\mathrm{V}^{2}$. Ovarian masses: Changing clinico histopathological trends. J Obstet Gynaecol India. 2015 Feb; 65(1):34-8.

12. Ashraf A, Shaikh S, Akram AIA, Kamal F, Ahmad N. The relative frequency and histopathological pattern of ovarian masses. Biomedica. 2012; 28(1):98-102.

13. Parmer P, Sehgal S, Mathur K, Yadav A. Histological study of ovarian tumors in a Tertiary Care Hospital. Int J Med Res Prof. 2017; 3(2):96-98. 


\section{AUTHORSHIP AND CONTRIBUTION DECLARATION}

\begin{tabular}{|c|l|l|l|}
\hline Sr. \# & \multicolumn{1}{|c|}{ Author(s) Full Name } & \multicolumn{1}{|c|}{ Contribution to the paper } & Author(s) Signature \\
\hline 1 & Maria Akmal & $\begin{array}{l}\text { Data collection, and manuscript } \\
\text { writing. } \\
\text { Manuscript review. }\end{array}$ \\
3 & Mahham Janjua & $\begin{array}{l}\text { Contribution literature review } \\
\text { and data analysis. } \\
\text { COntribution in manuscript } \\
\text { writing. } \\
\text { Review of literature and analysis. }\end{array}$ \\
\hline 5 & Zobia Jawad & Maria Imran &
\end{tabular}

